\title{
Stimulation of nitrous oxide production resulted from soil fumigation with chloropicrin
}

\author{
K. Spokas*, D. Wang \\ Department of Soil, Water, and Climate, University of Minnesota, St. Paul, MN 55108, USA
}

Received 23 January 2003; accepted 16 May 2003

\begin{abstract}
Agricultural soils are a major source of the atmospheric greenhouse gas nitrous oxide $\left(\mathrm{N}_{2} \mathrm{O}\right)$. Agronomic practices such as tillage and fertilizer applications can significantly affect the production and consumption of $\mathrm{N}_{2} \mathrm{O}$ because of alteration in soil physical, chemical, and biochemical activities. Soil fumigation is an agronomic practice used to control soil-borne disease pathogens, weeds, plant-parasitic nematodes, and fungi. The strong impact of fumigants on soil microorganisms can indirectly affect the production and/or consumption of $\mathrm{N}_{2} \mathrm{O}$ and would potentially alter net emissions from agricultural soils. Laboratory incubation and field soil fumigation studies were conducted to determine the potential impact of soil fumigation on the dynamics of $\mathrm{N}_{2} \mathrm{O}$ production. Laboratory soil incubations showed an eight-fold increase in the production rate of $\mathrm{N}_{2} \mathrm{O}$ as a consequence of chloropicrin (CP) fumigation. This stimulation effect was confirmed by a seven-fold increase in $\mathrm{N}_{2} \mathrm{O}$ emission rates in field plots following $\mathrm{CP}$ fumigation. The mechanism of $\mathrm{N}_{2} \mathrm{O}$ production appeared to be microbial related; however, additional work is needed to fully elucidate the pathways.
\end{abstract}

(C) 2003 Elsevier Ltd. All rights reserved.

Keywords: Greenhouse gas; $\mathrm{N}_{2} \mathrm{O}$ emission; Incubation; Flux chamber; Fumigants

\section{Introduction}

According to a USDA report, over 68,000 hectares of soil in the US is fumigated annually with methyl bromide $(\mathrm{MeBr})$ containing fumigant mixtures before mandatory reductions began in 1999, and over 250,000 hectares of soil are fumigated globally (USDA, 2002). Because of its large volatilization losses (Majewski et al., 1995; Yagi et al., 1995; Wang et al., 1999) and potential for depleting stratospheric ozone (Wofsy et al., 1975; Butler, 1995), MeBr is scheduled to be phased out in 2005 in the USA. A number of replacement fumigants are being actively studied in terms of efficacy and herbicidal functionality (USEPA, 2002). Soil fumigation is a common practice in agriculture using chemicals to control both microbiological organisms (soil-borne

\footnotetext{
*Corresponding author. Fax: + 1-612-625-2208.

E-mail address: kspokas@soils.umn.edu (K. Spokas).
}

disease pathogens, plant-parasitic nematodes, and fungi) and weeds. The major screening criteria that have been used for the $\mathrm{MeBr}$ replacements are: (a) lack of ozone depleting properties, and (b) efficacy for soil-borne pathogens and organisms. Chloropicrin (CP) is one of the successful replacements in terms of these properties. $\mathrm{CP}$ is also commonly used in mixtures with other fumigants (e.g. MeBr, 1,3-dichloropropene (1,3-D), and methyl isothiocyanate (MITC)) to promote broadspectrum efficacy and as a warning agent to the presence of fumigant vapors, since $\mathrm{CP}$ is a strong lachrymator.

Both biotic and abiotic transformations can result in mineralization of $\mathrm{CP}$ to precursors that would possibly be involved in the formation of $\mathrm{N}_{2} \mathrm{O}$. Some Pseudomonas species have been shown to successively dechlorinate CP $\left(\mathrm{CHCl}_{3} \mathrm{NO}_{2}\right)$ (Castro et al., 1983) and other chlorinated fumigants (van der Waarde et al., 1993; Poelarends et al., 1998). This is particularly important due to the prevalence of Pseudomonas in soils. However, 
the distribution of microbial populations is extremely heterogeneous, with populations localized around particulate organic matter (Rovira and Sands, 1971) and varying with different microenvironments (e.g. anaerobic/aerobic) coexisting within a few millimeters (Clarholm, 1981; Grundmann and Debouzie, 2000).

There are also abiotic pathways of CP degradation. Photolysis in air or in the shallow surface soil $(0-0.3 \mathrm{~mm}$ from the surface; Hebert and Miller, 1990; Konstantinou et al., 2001) or hydrolysis with water producing $\mathrm{CO}_{2}, \mathrm{Cl}^{-}, \mathrm{NO}_{3}^{-}$and $\mathrm{H}^{+}$(Castro and Besler, 1981). However, no reference has been made to increase production of $\mathrm{N}_{2} \mathrm{O}$ during the degradation of $\mathrm{CP}$.

Agricultural operations are a significant source of $\mathrm{N}_{2} \mathrm{O}$, accounting for $6.4 \mathrm{Tg} \mathrm{N}_{2} \mathrm{O}-\mathrm{N}$ per year or approximately one-third of total terrestrial emissions (Kroeze et al., 1999; Chang and Hao, 2001). On a molecule per molecule basis, the global warming potential (GWP) of $\mathrm{N}_{2} \mathrm{O}$ is approximately 300 times that of $\mathrm{CO}_{2}$ over a 100 -year time scale. Therefore, even small changes in $\mathrm{N}_{2} \mathrm{O}$ emission can have significant impact on global warming.

$\mathrm{N}_{2} \mathrm{O}$ can be formed by both nitrification and denitrification reactions. Nitrification is the microbial conversion of ammonium into nitrite and nitrate; denitrification is the anaerobic microbial reduction of nitrate and nitrite to nitrogen gas. These microbial processes are tightly coupled to each other, and also coupled to the microbial mineralization of organic matter (Firestone and Davidson, 1989).

$\mathrm{N}_{2} \mathrm{O}$ sources are not limited to nitrification and denitrification reactions. It has been determined that microbial transformations of $\mathrm{NO}$ to $\mathrm{N}_{2} \mathrm{O}$ can occur in well aerated soils (Schafer and Conrad, 1993; Venterea and Rolston, 2000a). In addition, abiotic pathways have been identified for the production of $\mathrm{N}_{2} \mathrm{O}$ from $\mathrm{HNO}_{2}$ in sterile soils (Venterea and Rolston, 2000b) and ammonium nitrate on atmospheric aerosols (Clemens et al., 1997).

Because microbial carbon and nitrogen liberation could occur following fumigation and $\mathrm{CP}$ degrades to nitrogen containing metabolites, it is anticipated that $\mathrm{N}_{2} \mathrm{O}$ emission would increase following soil fumigation with CP. The objective of this study was to examine the stimulation of $\mathrm{N}_{2} \mathrm{O}$ production through laboratory incubations and field flux measurements as a consequence of CP fumigation.

\section{Materials and methods}

Laboratory incubations were performed to determine if soil fumigation with $\mathrm{CP}$ would increase $\mathrm{N}_{2} \mathrm{O}$ production. Soil samples from five depth increments were collected prior to fumigation and stored at $4{ }^{\circ} \mathrm{C}$ until laboratory incubations could be performed. The soil is a Vilas loamy sand (sandy, mixed, frigid, Entic Haplorthod). Soil bulk density, moisture content, $\mathrm{pH}$, and fractions of sand, silt, clay, and total organic carbon (TOC) were measured for the five depth increments (Table 1). Bulk density was determined by the core method or the excavation method (Blake and Hartge, 1986) at locations where the metal core sampler could not be driven into the soil. Ten sub-samples from each depth were taken for bulk density analysis. Soil water content was determined by oven drying $10 \mathrm{~g}$ sub-samples at $105^{\circ} \mathrm{C}$ for $24 \mathrm{~h}$. Soil $\mathrm{pH}$ was measured in a $1: 1$ (v:v) slurry of soil and deionized water using a Hanna Instrument portable $\mathrm{pH} / \mathrm{EC} / \mathrm{TDS} /$ temperature probe. Soil texture and TOC were determined by the University of Minnesota Soil and Plant Testing Laboratory. The laboratory used the hydrometer method for texture and the loss on ignition method for TOC.

Prior to incubation studies, the soil was initially incubated in the dark for $10 \mathrm{~d}$ at room temperature $\left(22 \pm 2^{\circ} \mathrm{C}\right)$ in a high humidity aerobic environment to reactivate microbial colonies, following procedures similar to $\mathrm{Wu}$ et al. (1996). Then $5 \mathrm{~g}$ subsamples of the pre-conditioned soil were placed in $125 \mathrm{ml}$ serum vials (Wheaton Glass, Milville, NJ) and sealed with Teflonlined butyl rubber septa (Agilent Technologies, Palo Alto, CA). CP was injected through the sealed serum vial to prevent volatilization losses of the fumigant and incubated for $10 \mathrm{~d}$. To simulate the effect of an additional carbon source on $\mathrm{N}_{2} \mathrm{O}$ production rates, tests were also run with a glucose amendment $(0.5 \mathrm{mg}$ glucose $5 \mathrm{~g}^{-1}$ soil). Glucose amendments have been used as a simple carbon source to examine stimulation of

Table 1

Summary of soil properties ${ }^{\mathrm{a}}$

\begin{tabular}{llllllrr}
\hline Depth $(\mathrm{cm})$ & $\rho_{\mathrm{b}}\left(\mathrm{g} \mathrm{cm}^{-3}\right)$ & $\mathrm{pH}$ & $\theta(\%)$ & Sand $(\%)$ & Clay $(\%)$ & Silt $(\%)$ & TOC $(\%)$ \\
\hline $0-10$ & $1.49 \pm 0.07$ & $6.76 \pm 0.11$ & $16.8 \pm 0.9$ & 83.7 & 9.0 & 7.3 & 1.1 \\
$10-20$ & $1.63 \pm 0.12$ & $6.25 \pm 0.05$ & $16.1 \pm 0.6$ & 86.7 & 6.5 & 6.8 & 1.1 \\
$20-30$ & $1.72 \pm 0.11$ & $5.62 \pm 0.03$ & $9.8 \pm 0.5$ & 93.5 & 1.7 & 4.8 & 0.1 \\
$30-50$ & $1.77 \pm 0.21$ & $5.70 \pm 0.06$ & $8.4 \pm 0.5$ & 96.2 & 0.3 & 3.5 & $<0.1$ \\
$50-75$ & $1.75 \pm 0.25$ & $5.20 \pm 0.05$ & $8.2 \pm 0.4$ & 97.8 & 0.0 & 2.2 & $<0.1$ \\
\hline
\end{tabular}

${ }^{\mathrm{a}} \rho_{\mathrm{b}}=$ soil bulk density, $\theta=$ soil volumetric water content, TOC $=$ total organic carbon. 
$\mathrm{N}_{2} \mathrm{O}$ production (Speir et al., 1995; Nobre et al., 2001; Wheatley et al., 2001). Prior research has suggested a complex interaction between heterotrophic bacteria and nitrification rates (Wheatley et al., 2001). No CP injections were made in the soil controls or the glucose only treatments. Incubations of $\mathrm{CP}$ were also performed in glass beads due to the difficulty in sterilizing the soil completely as confirmed by $\mathrm{CO}_{2}$ respiration tests. The glass beads were used to see if $\mathrm{N}_{2} \mathrm{O}$ production resulted from the abiotic decomposition of $\mathrm{CP}$, but would not account for the abiotic interactions with the mineral components of the soil. The five different treatments were: (1) control (5 g soil); (2) soil (5g) and fumigant ( $0.3 \mathrm{mg}$ CP per vial); (3) glucose ( $0.5 \mathrm{mg}$ per vial) and soil (5 g); (4) glucose $(0.5 \mathrm{mg}$ per vial), CP ( $0.3 \mathrm{mg}$ per vial), and soil $(5 \mathrm{~g})$; and (5) glass beads $(5 \mathrm{~g})$ and $\mathrm{CP}(0.3 \mathrm{mg})$. Adding $0.3 \mathrm{mg} \mathrm{CP}$ in $5 \mathrm{~g}$ soil corresponds to $500 \mathrm{~kg} \mathrm{ha}^{-1}$ at bulk density of $1.65 \mathrm{~g} \mathrm{~cm}^{-3}$ and $0.5 \mathrm{~m}$ soil depth. All incubations were run in triplicate and conducted at room temperatures $\left(22 \pm 2^{\circ} \mathrm{C}\right)$.

Headspace gas samples were run on a GC system. The GC system consisted of a HP-5890 GC unit (Agilent Technologies, Palo Alto, CA) with an electron capture detector (ECD) that was used to quantify the amount of $\mathrm{N}_{2} \mathrm{O}$ in the gas samples. The injection used a $0.75 \mathrm{ml}$ gassampling loop, with helium as the carrier gas. The column used to separate $\mathrm{N}_{2} \mathrm{O}$ in the sample was a Porapak N $(2 \mathrm{~m} \times 0.32 \mathrm{~cm}$; Alltech, Deerfield, IL; $30 \mathrm{ml} \mathrm{min}^{-1}$ ), with a total analysis time of $8 \mathrm{~min}$ per injection. $\mathrm{Ar} / \mathrm{CH}_{4}$ was the make-up gas on the ECD $\left(60 \mathrm{ml} \mathrm{min}^{-1}\right)$. Column temperature was isothermal at $90^{\circ} \mathrm{C}$. The amount of $\mathrm{N}_{2} \mathrm{O}$ in the headspace samples was quantified through a multiple point external calibration based on height response of the peak for $\mathrm{N}_{2} \mathrm{O}$ from certified gas standards (Scott Specialty Gases).

Field $\mathrm{N}_{2} \mathrm{O}$ flux measurements were made at the Hayward State Nursery, located at Hayward, WI, which is approximately $450 \mathrm{~km}$ northwest of Madison, WI, USA. This location was selected due to ongoing research investigating the distribution, efficacy, and emission of $\mathrm{CP}$ and MITC following soil fumigation, and a previous study on fumigant efficacy by Juzwik et al. (1997). Three field flux sites were established for measuring $\mathrm{N}_{2} \mathrm{O}$ emissions. Two sites were located on the fumigated plots (one each on MITC and CP/MITC test plot, respectively) and the third site was in an adjacent untreated area (the control plot). Flux measurements were taken with static chambers with a minimum of four samples taken from each chamber (typically at 0, 5, 10, and $20 \mathrm{~min}$ ). Each air sample was $60 \mathrm{ml}$ in volume. The flux was calculated from the linear portion $\left(r^{2}>0.90\right)$ of $\mathrm{N}_{2} \mathrm{O}$ concentration increase in the chamber air as a result of the surface emissions:

flux $=\frac{V}{A}\left(\frac{\Delta C}{\Delta t}\right)$ where $V$ and $A$ are the volume and area of the chamber, respectively. $\Delta C$ is the concentration change over the time increment $\Delta t$. The chamber design was identical to the chambers used for monitoring greenhouse gas emissions from the surface of landfills (Bogner et al., 1997).

Daily $\mathrm{N}_{2} \mathrm{O}$ flux measurements were taken in the field for approximately $20 \mathrm{~d}$ following fumigation. Initially $22 \mathrm{ml}$ headspace vials (Kimble/Kontes, Dusseldorf, Germany) were capped with Teflon-lined butyl rubber septa (Kimble/Kontes, Dusseldorf, Germany). Just before sampling, the vials were evacuated in the field using a Precision ${ }^{\circledR}$ vacuum pump (ultimate vacuum was $1 \times 10^{-3}$ torr; model D-75, Fisher Scientific). A $60 \mathrm{ml}$ gas sample was then injected through the septum into the sealed headspace vial in the field, which resulted in overpressurization of the vial ( $\sim 2.7 \mathrm{~atm}$ pressure). After the vial was over-pressurized with the sample, it was stored in a field cooler (without ice). Headspace vials have been used to collect gas samples in prior studies (e.g. Liou et al., 2003) and the integrity of the sample is ensured if the over-pressurization is still present in the vial when it is analyzed in the laboratory.

In addition to the headspace vials, customized $11 \mathrm{ml}$ stainless steel gas containers (Spokas and Bogner, 1996; Bogner et al., 1997) that were previously developed for trace gas monitoring at landfills were also used. Briefly, each container consists of a $6.35 \mathrm{~mm}$ (i.d.) stainless steel tubing capped on one end with a Swagelok ${ }^{\mathbb{R}}$ (registered trademark of Swagelok Corp.) plug and the other end with a Swagelok ${ }^{\mathbb{R}}$ toggle valve consisting of a Teflonlined valve stem. These containers were also evacuated directly in the field and $60 \mathrm{ml}$ of the respective gas sample was injected into the containers $(\sim 5.5 \mathrm{~atm}$ pressure). These containers were also placed in the field cooler (without ice) after sampling. Unlike the headspace vials, these containers preserved the integrity of the samples without leakage. However, limitations on the number of the available stainless steel containers restricted the total number of flux samples that were taken with these containers. In summary, there were a total of 276 gas samples taken at the field site, 36 samples taken with the stainless steel containers and 240 with the headspace vials. However, only 96 of the headspace vials preserved pressurization upon receipt at the laboratory. The lack of pressure in the vial is an indication that leakage occurred at some point after the sampling in the field. Therefore, to ensure the integrity of the collected data any vial that was not pressurized was eliminated. Furthermore, each flux sample is a set of four vials and only nine flux samples had all four samples preserved (36 vials).

Data were analyzed using an analysis of variance (ANOVA) procedure for independent samples to test for statistically significant differences using MINITAB (Minitab, Inc., State College, PA). If there was a 
significant difference among the factors, as indicated by a significant $F$-ratio, the Tukey's honest significant difference (HSD) test was performed to determine which pair-wise interactions were significantly different at the $p<0.01$ and 0.05 levels.

\section{Results and discussion}

Measured $\mathrm{N}_{2} \mathrm{O}$ production rates from the laboratory incubations are summarized in Table 2. Overall, higher $\mathrm{N}_{2} \mathrm{O}$ production was found in $\mathrm{CP}$ treated soil with or without the glucose addition. Because of the large standard deviation (SD) values in the CP treated soil, the increase in $\mathrm{N}_{2} \mathrm{O}$ production was statistically significant $(p<0.01)$ only for the $0-10$ and $50-75 \mathrm{~cm}$ depth intervals (Table 3). The lack of statistically significant differences between all the treatments was caused by the large variability in the production rates of $\mathrm{N}_{2} \mathrm{O}$. High variability in the $\mathrm{N}_{2} \mathrm{O}$ production rates has also been reported in other studies (e.g. Robertson, 1994; Frolking et al., 1998; Hénault et al., 1998; Dilly, 2001). Significant differences $(p<0.01)$ were found between the glass bead control and all soil-CP treatments with the exception of the $20-30 \mathrm{~cm}$ soil-CP treatment without glucose (Table 3).

Overall, there was a stimulation of $\mathrm{N}_{2} \mathrm{O}$ production with the glucose addition (Table 2), which is in agreement with results found in other studies (Nobre et al., 2001; Wheatley et al., 2001). Adding glucose alone (without $\mathrm{CP}$ ) did not affect $\mathrm{N}_{2} \mathrm{O}$ production rate. This could indicate insufficient $\mathrm{N}$ availability in the soil to support $\mathrm{N}_{2} \mathrm{O}$ production. The combination of glucose and $\mathrm{CP}$ increased the production rate of $\mathrm{N}_{2} \mathrm{O}$ as compared to the soil control and was statistically significant $(p<0.01)$ in the $0-10$ and $50-75 \mathrm{~cm}$ intervals (Table 3). Similar to the findings by Firestone and Davidson (1989) and Nobre et al. (2001), the highest production rate of $\mathrm{N}_{2} \mathrm{O}$ occurred in the surface soils
$(0-20 \mathrm{~cm}$, Table 2$)$ where nutrients and the number of microbes would likely be more abundant.

As an example, increases in $\mathrm{N}_{2} \mathrm{O}$ concentration in the headspace for the $50-75 \mathrm{~cm}$ soil samples were shown in Fig. 1 for both fumigant only and fumigant with glucose treatments. Gas samples from the incubations were analyzed on day $0,1,3,6$, and 10. Without glucose addition, concentrations of $\mathrm{N}_{2} \mathrm{O}$ in the headspace following fumigation with $\mathrm{CP}$ were slightly higher than the controls, and about $8 \%$ increase was found after day 6 (Fig. 1a). Adding glucose did not affect $\mathrm{N}_{2} \mathrm{O}$ concentrations in the controls; however, the combination of glucose addition and CP fumigant drastically increased $\mathrm{N}_{2} \mathrm{O}$ concentrations starting $1 \mathrm{~d}$ after the incubation. About a 70\% increase was observed after day 6 (Fig. 1b).

Field flux measurements of $\mathrm{N}_{2} \mathrm{O}$ emission are summarized in Fig. 2. In the non-fumigated control plots $\mathrm{N}_{2} \mathrm{O}$ fluxes remained about $1 \mathrm{mg} \mathrm{m}^{-2} \mathrm{~d}^{-1}$ for the

Table 3

Statistically significant differences between treatments as a function of depth in laboratory incubations ${ }^{\mathrm{a}}$

\begin{tabular}{lll}
\hline Depth $(\mathrm{cm})$ & \multicolumn{2}{l}{ Significant interactions $(p<0.01)$} \\
\cline { 2 - 3 } & No amendments & Glucose amendment \\
\hline $0-10$ & $\begin{array}{l}\text { Control } \times \mathrm{CP} \\
\mathrm{CP} \times \mathrm{GB}\end{array}$ & $\begin{array}{l}\text { Control } \times \mathrm{CP} \\
\mathrm{CP} \times \mathrm{GB}\end{array}$ \\
& $\mathrm{CP} \times \mathrm{GB}$ & $\mathrm{CP} \times \mathrm{GB}$ \\
& F-ratio not significant & $\mathrm{CP} \times \mathrm{GB}$ \\
20-30 & $\mathrm{N} / \mathrm{A}$ & $\mathrm{N} / \mathrm{A}$ \\
$30-50$ & $\mathrm{Control} \times \mathrm{CP}$ & $\mathrm{CP} \times \mathrm{GB}$ \\
$50-75$ & $\begin{array}{l}\text { Control } \times \mathrm{GB} \\
\mathrm{CP} \times \mathrm{GB}\end{array}$ & $\mathrm{Control} \times \mathrm{CP}$ \\
& &
\end{tabular}

${ }^{\mathrm{a}} \mathrm{CP}=\mathrm{CP}$ and soil treatment, $\mathrm{GB}=$ glass bead treatment, Control $=$ soil only, $\mathrm{N} / \mathrm{A}=$ not available.

Table 2

Cumulative $\mathrm{N}_{2} \mathrm{O}$ production in laboratory incubations (calculated on day 6) ${ }^{\mathrm{a}}$

\begin{tabular}{|c|c|c|c|c|}
\hline \multirow[t]{2}{*}{ Depth (cm) } & \multicolumn{2}{|l|}{ No glucose } & \multicolumn{2}{|l|}{ Glucose amendment } \\
\hline & $\begin{array}{l}\text { Control } \\
\left(\mu \mathrm{g}-\mathrm{N}_{2} \mathrm{O} \text { kg-soil }{ }^{-1} \mathrm{~d}^{-1}\right)\end{array}$ & $\mathrm{CP}$ & 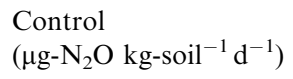 & $\mathrm{CP}$ \\
\hline $0-10$ & $0.10 \pm 0.03$ & $0.87 \pm 0.32$ & $0.15 \pm 0.03$ & $1.87 \pm 0.62$ \\
\hline $10-20$ & $0.12 \pm 0.07$ & $0.68 \pm 0.37$ & $0.13 \pm 0.09$ & $1.36 \pm 0.87$ \\
\hline $20-30$ & $0.08 \pm 0.05$ & $0.40 \pm 0.28$ & $0.10 \pm 0.04$ & $0.86 \pm 0.58$ \\
\hline $30-50$ & $\mathrm{~N} / \mathrm{A}$ & $\mathrm{N} / \mathrm{A}$ & $\mathrm{N} / \mathrm{A}$ & $\mathrm{N} / \mathrm{A}$ \\
\hline $50-75$ & $0.06 \pm 0.04$ & $0.13 \pm 0.02$ & $0.05 \pm 0.02$ & $0.25 \pm 0.06$ \\
\hline Glass beads & $\mathrm{N} / \mathrm{A}$ & $0.03 \pm 0.03$ & $\mathrm{~N} / \mathrm{A}$ & $0.03 \pm 0.02$ \\
\hline
\end{tabular}

\footnotetext{
${ }^{\text {a }} \mathrm{CP}=$ chloropicrin; values are mean $\pm \mathrm{SD}(n=3), \mathrm{N} / \mathrm{A}=$ not available.
} 

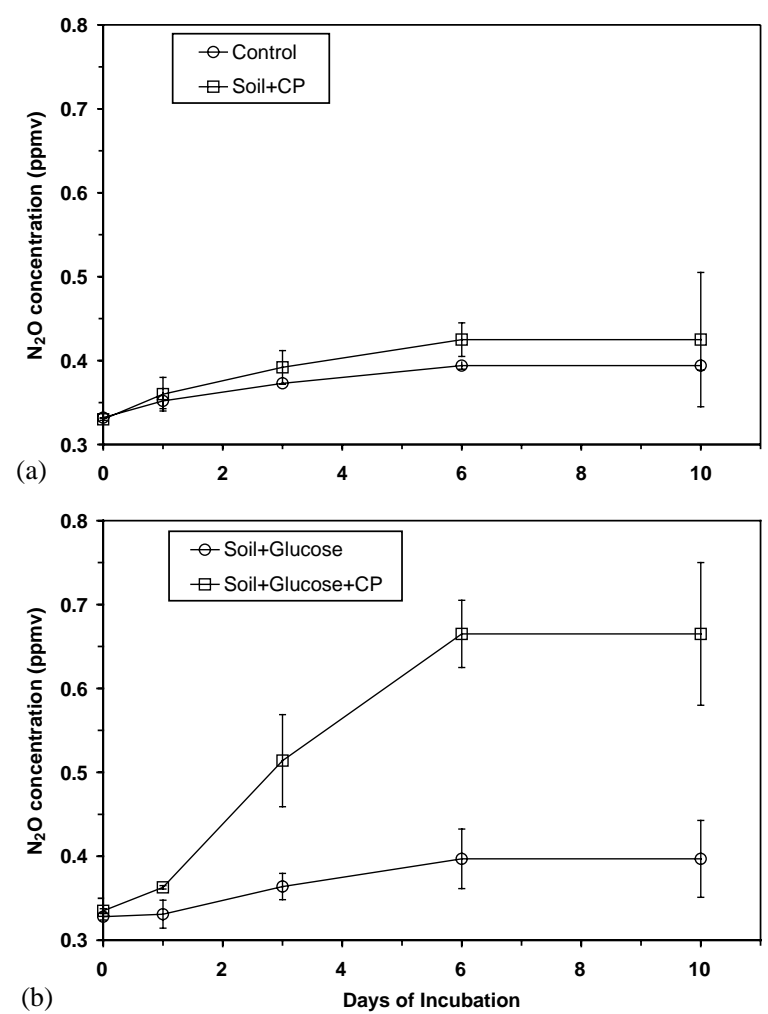

Fig. 1. Headspace concentration of $\mathrm{N}_{2} \mathrm{O}$ versus incubation time for $50-75 \mathrm{~cm}$ depth increment: (a) CP only, and (b) CP and glucose amendment. Error bars in the figure represent \pm one $\mathrm{SD}$ of the triplicate samples.

20-d measurement period (Fig. 2), and the rates were comparable to fluxes measured in agricultural soils (Smith et al., 1998; Kravchenko et al., 2002). $\mathrm{N}_{2} \mathrm{O}$ fluxes in the $\mathrm{CP} / \mathrm{MITC}$ treatment were significantly higher ( $p<0.05$ ), about 3-7 times of that of the control for the first $10 \mathrm{~d}$. The magnitude of the influence could be even higher immediately following fumigation. The flux rates appeared to have decreased over time, returning to near background levels. These high emission rates were in the same order of magnitude as in agricultural fields that received nitrogen fertilizers such as ammonium sulfate or urea (Breitenbeck et al., 1980).

Plots that received only MITC fumigation did not show changes in $\mathrm{N}_{2} \mathrm{O}$ emissions compared to the nonfumigated control (Fig. 2). MITC inhibits nitrification in sandy and clay loam soils (Bending and Lincoln, 2000). In aerobic soils the decomposition products of MITC that have been detected are carbon dioxide, sulfate, ammonia, and nitrate (BASF, 2002). So even though MITC decomposes into nitrogen containing compounds, there was no impact detected on the $\mathrm{N}_{2} \mathrm{O}$ emissions over the $20-\mathrm{d}$ period. This result indicates that

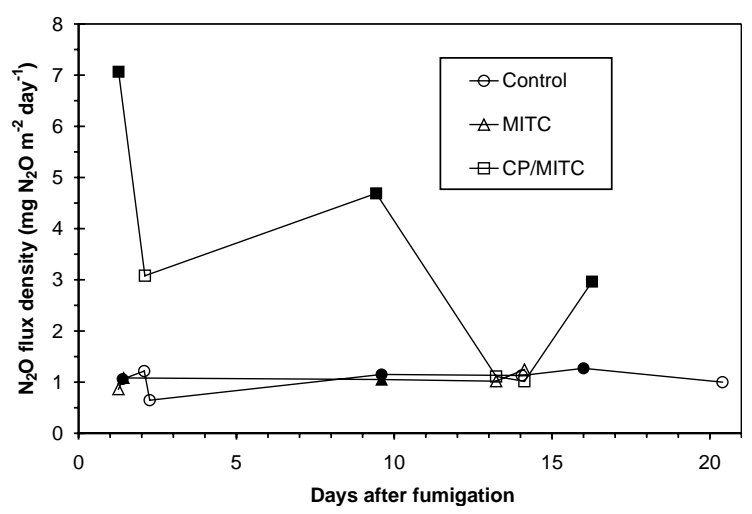

Fig. 2. Emission flux density of $\mathrm{N}_{2} \mathrm{O}$ from field plots fumigated with MITC or a mixture of CP and MITC, and an adjacent non-fumigated plot (control). Solid symbol indicate samples collected in the stainless steel containers, and open symbols represent the samples collected in headspace vials.

the effect of soil fumigation on $\mathrm{N}_{2} \mathrm{O}$ production could be fumigant specific.

It was hypothesized that $\mathrm{N}_{2} \mathrm{O}$ production was related to soil microbial processes for two reasons. The first was that the rate of $\mathrm{N}_{2} \mathrm{O}$ production declines with depth. The surface soil would be more abundant with nutrients and microbes. Therefore, there should be higher rates in the surface soils if microbes are involved in $\mathrm{N}_{2} \mathrm{O}$ production. Secondly, the concentration build-up of $\mathrm{N}_{2} \mathrm{O}$ in the laboratory incubations had the same appearance as a microbial growth curve, with a slight lag time followed by an exponential growth phase (Fig. 1). This is further supported by the fact that there was no change in the $\mathrm{N}_{2} \mathrm{O}$ production in the glass bead incubations due to the absence of microbes.

A potential concurrent mechanism for the increased $\mathrm{N}_{2} \mathrm{O}$ production after soil fumigation with $\mathrm{CP}$ could be a consequence of abiotic and biotic breakdown of CP to $\mathrm{N}$-compounds (nitrate, nitrite, and ammonia). Increased inorganic $\mathrm{N}$ levels $\left(\mathrm{NO}_{3}^{-}\right.$and $\left.\mathrm{NH}_{4}^{+}\right)$in the soil have already been measured following soil fumigation with CP and MITC (Hansen et al., 1990). In addition, it is postulated that there is also a source of inorganic $\mathrm{N}$ and $\mathrm{C}$ from the mineralization of killed microorganisms resulting from fumigation (Hansen et al., 1990; Jenkinson and Powlson, 1976). These N-sources would then be available for microbial-aided denitrification, nitrification, coupled nitrification-denitrification, and/or nitrifier denitrification reactions leading to $\mathrm{N}_{2} \mathrm{O}$ production (Wrage et al., 2001). Nitrifier denitrification follows the pathway $\mathrm{NH}_{3} \rightarrow \mathrm{NO}_{2}^{-} \rightarrow \mathrm{N}_{2} \mathrm{O}$ involving solely nitrifier organisms (Wrage et al., 2001), whereas the coupled nitrification-dentrification involves both groups (nitrifiers and denitrifiers) of microorganisms (Arah, 1997). 
As a consequence of $\mathrm{CP}$ fumigation, the denitrification potential decreased compared to non-fumigated soils in laboratory slurry incubations (Klose, 2002, personal communications). If this reduction in the denitrification occurs in the field, this could support the nitrifier denitrification or nitrification pathways since the denitrifier microbes are not involved. The nitrification pathways would also be substantiated by the lack of $\mathrm{N}_{2} \mathrm{O}$ stimulation in the MITC fumigated field plots where nitrification reactions has been shown to be inhibited by MITC (Bending and Lincoln, 2000). In addition, $\mathrm{N}_{2} \mathrm{O}$ production in the laboratory incubation ceased when oxygen levels declined below $15 \%$ in the incubations (after day 6, data not shown) thus reducing the likelihood that the $\mathrm{N}_{2} \mathrm{O}$ production was from anaerobic denitrification. The increase in $\mathrm{N}_{2} \mathrm{O}$ production resulting from the glucose amendments would indicate that the production of $\mathrm{N}_{2} \mathrm{O}$ is the result of a series of complex hetrotrophic interactions as suggested by Wheatley et al. (2001).

\section{Conclusions and implications}

The goal of this research was to obtain an assessment of the effects of soil fumigation on $\mathrm{N}_{2} \mathrm{O}$ emissions. Based on the laboratory and field measurements, it is evident that soil fumigation with $\mathrm{CP}$ can alter the dynamics of $\mathrm{N}_{2} \mathrm{O}$ in the soil and emissions to the atmosphere for the soil type analyzed in this study. The results presented here may not be extrapolated to other soil types until further testing. It also appears from the field data that different fumigant compounds have a different effect on $\mathrm{N}_{2} \mathrm{O}$ emissions, with $\mathrm{CP}$ stimulating $\mathrm{N}_{2} \mathrm{O}$ production but no effect with MITC fumigation. The process of soil fumigation could cause long lasting changes in the make-up and biodiversity of soil microorganisms. This will result in changes in the balance of $\mathrm{N}_{2} \mathrm{O}$ between soils and the atmosphere during and after fumigation. These effects need to be quantified in order to assess the potential global impact of soil fumigation on $\mathrm{N}_{2} \mathrm{O}$ budgets. A better understanding on the interactions between different fumigant formulations and their potential on $\mathrm{N}_{2} \mathrm{O}$ emissions can be particularly useful as a screening tool for selecting more sustainable options for soil fumigants.

\section{Acknowledgements}

The authors would like to acknowledge Rodney Venterea, Jennifer King, and Maya Kuratomi for their helpful inputs. We also thank USDA-CSREES for a grant that has made this work possible.

\section{References}

Arah, J.R.M., 1997. Apportioning nitrous oxide fluxes between nitrification and denitrification using gas-phase mass spectrometry. Soil Biology and Biochemistry 29, 1295-1299.

BASF, 2002. Product information on Basamid-G soil fumigant: Fate of Dazomet soil metabolites. (www.basf.de/en/ produkte) BASF Aktiengesellschaft, Germany.

Bending, G.D., Lincoln, S.D., 2000. Inhibition of soil nitrifying bacteria communities and their activities by glucosinolate hydrolysis products. Soil Biology and Biochemistry 32, 1261-1269.

Blake, G.R., Hartge, K.H., 1986. Bulk density. In: Klute, A. (Ed.), Methods of Soil Analysis, Part I. Physical and Mineralogical Methods: Agronomy Monograph no. 9 (2nd Edition). Soil Science Society of America, Madison, WI, pp. 363-375.

Bogner, J.A., Spokas, K.A., Burton, E., 1997. Kinetics of methane oxidation in a landfill cover soil: temporal variations, a whole-landfill oxidation experiment, and modeling of net $\mathrm{CH}_{4}$ emissions. Environmental Science and Technology 31, 2504-2514.

Breitenbeck, G.A., Blackmer, A.M., Bremner, J.M., 1980. Effects of different nitrogen fertilizers on emissions of nitrous oxide from soil. Geophysical Research Letters 7, $85-88$.

Butler, J.H., 1995. Methyl bromide under scrutiny. Nature 376, 469-470.

Castro, C.E., Besler, N.O., 1981. Photohydrolysis of methyl bromide and chloropicrin. Journal of Agriculture and Food Chemistry 29, 1005-1008.

Castro, C.E., Wade, R.S., Besler, N.O., 1983. Biodehalogenation. The metabolism of chloropicrin by Pseudomonas sp. Journal of Agricultural Food Chemistry 21, 1184-1187.

Chang, C., Hao, X., 2001. Source of $\mathrm{N}_{2} \mathrm{O}$ emission form soil during freezing and thawing. Annales Rei Botanicae 41, 49-60.

Clarholm, M., 1981. Protozoan grazing of bacteria in soil: impact and importance. Microbial Ecology 7, 343-350.

Clemens, J., Burkhardt, J., Goldbach, J., 1997. Abiogenic nitrous oxide formation on aerosols. Atmospheric Environment 31, 2961-2964.

Dilly, O., 2001. Microbial respiratory quotient during basal metabolism and after glucose amendment in soils and litter. Soil Biology and Biochemistry 33, 117-127.

Firestone, M., Davidson, E., 1989. Exchange of Trace Gases between Terrestrial Ecosystems and the Atmosphere. Wiley, Chichester, England, pp. 7-21.

Frolking, S.E., Mosier, A.R., Ojima, D.S., Li, C., Parton, W.J., Potter, C.S., Priesack, E., Stenger, R., Haberbosch, C., Dorsch, P., Flessa, H., Smith, K.A., 1998. Comparison of no emissions from soils at three temperate agricultural sites: simulations of year-round measurements by four models. Nutrient Cycling in Agroecosystems 52, 77-105.

Grundmann, G.L., Debouzie, D., 2000. Geostatistical analysis of the distribution of $\mathrm{NH}_{4}+$ and $\mathrm{NO}_{2}$ - oxidizing bacteria and serotypes at the millimeter scale along a soil transect. Federation of European Microbiological Societies Microbiology Ecology 34, 57-262.

Hansen, E.M., Myrold, D.D., Hamm, P.B., 1990. Effects of soil fumigation and cover crops on potential pathogens, 
microbial activity, nitrogen availability, and seedling quality in conifer nurseries. Phytopathology 80, 698-704.

Hebert, V.R., Miller, G.C., 1990. Depth dependence of direct and indirect photolysis on soil surfaces. Journal of Agriculture and Food Chemistry 38, 913-918.

Hénault, C., Devis, X., Lucas, J.L., Germon, J.C., 1998. Influence of different agricultural practices (type of crop, form of $\mathrm{N}$-fertilizer) on soil nitrous oxide emissions. Biology and Fertility of Soils 27, 299-306.

Jenkinson, D.S., Powlson, D.S., 1976. The effects of biocidal treatments on the metabolism in soil V. A method for measuring soil biomass. Soil Biology and Biochemistry 8, 209-213.

Juzwik, J., Stenlund, D.L., Allmaras, R.R., Copeland, S.M., McRoberts, R.M., 1997. Incorporation of tracers and dazomet by rotary tillers and a spading machine. Soil and Tillage Research 41, 237-248.

Konstantinou, I.K., Zarkadis, A.K., Albanis, T.A., 2001. Photodegradation of selected herbicides in various natural waters and soils under environmental conditions. Journal of Environmental Quality 30, 121-130.

Kravchenko, I., Boeckx, P., Galchenko, V., Van Cleemput, O., 2002. Short and medium-term effects on $\mathrm{NH}_{4}+$ on $\mathrm{CH}$ and $\mathrm{N}_{2} \mathrm{O}$ fluxes in arable soil with a different texture. Soil Biology and Biochemistry 34, 669-678.

Kroeze, C., Mosier, A., Bouwman, L., 1999. Closing the global $\mathrm{N}_{2} \mathrm{O}$ budget: a retrospective analysis 1500-1994. Global Biogeochemical Cycles 13, 1-8.

Liou, R.M., Huang, S.H., Lin, C.W., 2003. Methane emission from fields with differences in nitrogen fertilizers and rice varieties in Taiwan paddy soils. Chemosphere 50, 237-246.

Majewski, M.S., McChesney, M.M., Woodrow, J.E., Prueger, J.H., Seiber, J.N., 1995. Aerodynamic measurements of methyl bromide volatilization from tarped and nontarped fields. Journal of Environmental Quality 24, 742-752.

Nobre, A.D., Keller, M., Crill, P.M., Harriss, R.C., 2001. Short-term nitrous oxide profile dynamics and emissions response to water, nitrogen and carbon additions in two tropical soils. Biology and Fertility of Soils 34, 363-373.

Poelarends, G.J., Wilkens, M., Larkin, M.J., van Elsas, J.D., Janssen, D.B., 1998. Degradation of 1,3-dichloropropene by Pseudomonas cichorii 170. Applied and Environmental Microbiology 64, 2931-2936.

Robertson, K., 1994. Nitrous oxide emission in relation to soil factors at low to intermediate moisture levels. Journal of Environmental Quality 23, 805-809.

Rovira, A.D., Sands, D.C., 1971. Fluorescent pseudomonadsa residual component in the soil microflora? Journal of Applied Bacteriology 34, 253-259.

Schafer, F., Conrad, R., 1993. Metabolism of nitric oxide by Pseudomonas stutezi in culture and soil. Federation of European Microbiological Societies Microbiology Ecology 102, 119-127.
Smith, K.A., Thomson, P.E., Clayton, H., McTaggart, I.P., Conen, F., 1998. Effects of temperature, water content and nitrogen fertilization on emissions of nitrous oxide by soils. Atmospheric Environment 32, 3301-3309.

Speir, T.W., Kettles, H.A., More, R.D., 1995. Aerobic emissions of $\mathrm{N}_{2} \mathrm{O}$ and $\mathrm{N}_{2}$ from soil cores: factors influencing production from $13 \mathrm{~N}$-labelled $\mathrm{NO}_{3}^{-}$and $\mathrm{NH}_{4}^{+}$. Soil Biology and Biochemistry 27, 1299-1306.

Spokas, K., Bogner, J., 1996. Comprehensive sampling and analysis of landfill gas: customized analysis of trace components (CATC). Proceedings of the 19th Internal Madison Waste Conference, Department of Engineering Professional Development, University of Wisconsin, Madison, WI, 25-26 September.

USEPA, 2002. Ozone Depletion Rules and Regulations: Methyl Bromide Q\&A (newsletter). US Environmental Protection Agency, Washington, DC.

USDA, 2002. The status of MeBr alternatives. In: Methyl Bromide Alternatives Newsletter, Vol. 8 (1), July, USDAARS, Beltsville, MD, 2002.

van der Waarde, J.J., Kok, R., Janssen, D.B., 1993. Degradation of 2-chloroallyl alcohol by a Pseudomonas sp. Applied Environmental Microbiology 59, 528-535.

Venterea, R., Rolston, D.E., 2000a. Mechanisms and kinetics of nitric and nitrous oxide production during nitrification in agricultural soil. Global Environmental Change 6, 303-316.

Venterea, R., Rolston, D.E., 2000b. Nitric and nitrous oxide emissions following fertilizer application to agricultural soil: biotic and abiotic mechanisms and kinetics. Journal of Geophysical Research 105, 15117-15129.

Wang, D., Yates, S.R., Gan, J., Knuteson, J.A., 1999. Atmospheric volatilization of methyl bromide, 1,3-dichloropropene, and propargyl bromide through two plastic films: transfer coefficient and temperature effect. Atmospheric Environment 33, 401-407.

Wheatley, R.E., Ritz, K., Crabb, D., Caul, S., 2001. Temporal variations in potential nitrification dynamics in soil related to differences in rates and types of carbon and nitrogen inputs. Soil Biology and Biochemistry 33, 2135-2144.

Wofsy, S.C., McElroy, M.B., Yung, Y.L., 1975. The chemistry of atmospheric bromine. Geophysical Research Letters 2, 215-218.

Wrage, N., Velthof, G.L., van Beusichen, M.L., Oenema, O., 2001. Role of nitrifer denitrification in the production of nitrous oxide. Soil Biology and Biochemistry 33, 1723-1732.

Wu, J., Brookes, P.C., Jenkinson, D.S., 1996. Evidence for the use of a control in the fumigation-incubation method of measuring microbial biomass carbon in soil. Soil Biology and Biochemistry 28, 511-518.

Yagi, K., Williams, J., Wang, N.Y., Cicerone, R.J., 1995. Atmospheric methyl bromide from agricultural soil fumigations. Science 267, 1979-1981. 